\title{
Discussion on the Value of University Library in Campus Culture Construction
}

\author{
Xiuhua Ma and Gemin Li \\ Jilin Agricultural University Library, Changchun, China
}

Keywords: University library; Campus culture; Value

\begin{abstract}
The campus is a cradle of dreams, and it is beautiful and full of hope for every student. The good campus cultural atmosphere can cultivate students' correct values, noble moral sentiments and rich ideological connotations. Campus culture is an important embodiment of university civilization and an important part of students' spiritual civilization construction. University library is an important place for students to acquire knowledge and life wisdom outside the classroom and it has an indelible significance in the construction of spiritual culture among the campus culture construction.
\end{abstract}

\section{Introduction}

To construct high quality campus culture is a complicated and systematic engineering. University library is the collection and distribution center of knowledge, information and literature. As one of the important places for students to acquire knowledge, university library is also an important pillar for campus culture construction and an important gateway for campus to develop high quality campus culture. Therefore, the university library must shoulder the important task of constructing campus culture, and strive for the construction of high quality campus culture.

\section{Connotation of Campus Culture}

"Campus culture" is an abstract concept; the literal comprehension of "campus culture" shows that the word "culture" is the embodiment of spiritual environment and cultural atmosphere, namely, a type of unique spiritual environment that exists only in higher education institutions. However, the campus culture is not only limited to the spiritual and cultural aspects, every grass and tree on the campus and the beauty and the strong humanistic spirit and the concept contained in every campus building will have profound impact on the psychological development of campus students.

However, the author believes that the important elements of campus culture are still dominated by spiritual environment and cultural atmosphere. A person or a collective can show the special character that is different from others or other collectives, the main role is the spiritual and cultural influence, although they're also influenced from the material aspect. Similarly, in order to make the students in a university to have the unique temperament, we also need to establish excellent spiritual culture in the university to render the students' spirit, so they can keep striving toward the positive, optimistic and upward spiritual levels.

\section{Value of University Library in Construction of Campus Culture}

\section{University Library is the Important Place for Campus Cultural Activities}

Education is not only carried out in universities, many institutions outside the campus can also have the same function; university library is on top of these educational institutions. In most institutions of higher learning, libraries are built in the middle of the campus or in the prominent position, so that we can see the importance of the university libraries in the construction of campus culture. Moreover, the university libraries generally have elegant and magnificent architectural style, so the students can have reading experience in an elegant environment.

In addition, the libraries are also of modern styles, such as: advanced computer retrieval equipment, abundant library resources, which bring modern fast-pace experience while they provide 
students with some convenience. University library is not only an important place for students to read, but also important place for students to learn knowledge and exchange ideas. Comfortable reading environment and good order can also play an active role for cultivating noble moral sentiments and good personality accomplishment for students.

The core content of the campus culture construction is the construction of spiritual culture, and the university library is one of the key contents of spiritual construction. This is because the university library not only has rich collection resources, but also has good cultural atmosphere and elegant environment, to delight people's spirit and relax people's mood. The university library can let students learn knowledge in an active atmosphere, so the students can study as a kind of enjoyment, and are more willing to come to the library.

\section{University Library is Collection and Distribution Center of Campus Literature Resources}

University library is an important place for students to sort out and check document literature, and the second classroom for students to acquire knowledge. Therefore, library can influence the cultural accomplishment and knowledge structure of university students. The university library should maximize the reserves and quality of literature resources, to provide solid foundation for improving students' quality and acquisition of scientific and cultural knowledge, and provide a good spiritual environment for the cultural life of university students.

The reserve and quality of literature in university libraries play an important role in the growth of university students. The good university libraries can not only provide rich scientific knowledge and advanced life concept to university students, but also plays an important role in the formation of good quality of university students and the cultivation of noble moral sentiments. They can cultivate students' right outlook on life, values and world view.

The literature resources of university libraries reflect the cultural accomplishment and humanistic spirit of this university. At this stage, the publications are of a wide range of categories and mixed qualities, so the library management personnel need to be able to select outstanding journals from them for university students to read and provide students with high quality spiritual food. The library management personnel must keep pace with the times, actively understands the reading requirements of teachers and students, and carries out the collection work of books according to these requirements; the university libraries should provide better services to university students and teachers on the basis of the mainstream ideology of the campus.

The university libraries are both the literature collection centers and the recording centers of campus culture, and they collect the documentary literature that reflects the campus culture; for example: the campus journals that reflect the development history of the campus; such type of publications are most fully collected in the university libraries, to provide specific reference materials for the research of campus culture and campus history.

As people pay more and more attention to the university libraries, university libraries continuously expand the building area, improve service consciousness and enhance the degree of openness; starting from every angle, the university libraries have the service purpose of achieving the satisfaction of students and teachers, comprehensively improve the influence of university libraries, so the students can freely swim in the ocean of knowledge.

Because of the rapid development of network in the current era, people can obtain knowledge and information through various media, so the university libraries should also keep pace with the times to provide online reading market. The university libraries should avoid the extracurricular time of university students to be occupied by adverse cultural information, but should actively guide students to correct ideological direction, and contribute rich and meaningful literature resources to the readers, and provide a powerful spirit for the healthy growth of university students.

\section{University Libraries are Cultural Centers of Campus}

University libraries are not only the campus literature resource centers, but also cultural centers of the campus; the university libraries not only have rich collection resources, but also rich audio-visual data, as well as some hardware facilities, such as: exhibition hall, to add rich colors for campus cultural life; they're important organizers and communicators of campus culture; the university libraries not only provide university students with scientific and cultural knowledge, but 
also cultivate their noble artistic accomplishment and aesthetic outlook. Some universities may hold picture exhibition, photography exhibition, foreign culture introduction and scientific knowledge exhibition in their libraries; although due to the limited size of the exhibition hall, the exhibition scale is relatively small, the university libraries add rich colors for the amateur cultural life of university students, and play the role of art edification for university students; in the small exhibition hall, the unique exhibition achieved the desired effect. The university libraries also hold some art lectures from time to time, which are very popular among readers.

In order to cultivate good artistic accomplishment of university students, the university libraries are generally equipped with high-quality audio-visual equipments, and will collect excellent films and television works for watch and experience by university students. For example, some universities will regularly hold elective appreciation courses of film and television music, classic music, classical music masterpiece and domestic and foreign outstanding film and broadcasting works, to help students improve artistic accomplishments.

In the university libraries, the environment of the university libraries is a unique art, and the layout of the university libraries is also very exquisite. For example, some university libraries will choose some famous paintings to decorate the walls, so the environment is not only beautiful, but also can edify and educate the artistic accomplishments of students.

Although the university libraries try best to cultivate excellent students, some aspects cannot achieve the satisfied effect due to various restrictions; this needs us to work hard together, to provide excellent spiritual cultural homeland for university students.

\section{University Libraries are Ideological and Moral Cultivating Centers of University Students}

University students are generally regarded as a group with high academic level, but they're often ignored as a noble minded group. However, there are some individual exceptional cases; for example: the library seats holding, books stealing, vandalism, book damage and impolite behavior against the management personnel. For such uncivilized behaviors, the library management personnel should shoulder the responsibility of teachers, to criticize and educate such students, and guide them to the correct orientation. It is not only the teacher's responsibility but also the common responsibility of the whole society to cultivate the university students with higher knowledge and noble ideology and morality. University students with high knowledge and low quality are not the talents required by the country, nor can they be the backbone of the country.

The university libraries are the direct windows of the campus culture construction, and they also have direct influence on the students. In the university libraries, the library management personnel have direct contact with the students. Therefore, as management personnel of libraries, they should have high sense of responsibility and sense of mission, give full play to their own advantages, and improve their own cultural and moral qualities. In the process of providing services to each student, they should improve their own rich cultural knowledge and noble professional quality to bring a subtle influence to the students, and guide the students to study hard in the right direction.

\section{Conclusion}

The university libraries are the spiritual homeland of students; when the students recalled their alma mater, they'll remember the good time they learned and read in the libraries. Therefore, the libraries play an indelible important role in the construction of campus culture. University libraries are the main places of campus cultural activities and the material base and important guarantee of campus cultural activities. The university libraries can greatly promote the development of campus culture. This paper researches the importance of university libraries in the construction of campus culture, aiming to improve the significance of libraries in the understanding of campus management personnel, so they can improve the libraries hardware facilities and supporting facilities. In this way, the campus culture can be more widely spread, to improve knowledge reserves of university students, affect the moral cultivation of university students and strive to cultivate high-quality and highly educated modern university students. 


\section{References}

[1] Gao Wen. Discussion on Influence of University Libraries on Campus Culture Construction [J]. New West (Theoretical Edition), 2015, (14): 117+114.

[2] Wang Lina. On the Role of University Libraries in Construction of Campus Culture [J]. Communication and Copyright, 2016, (01): 144-145.

[3] Ma Jihua. Discussion on Role of University Libraries in Campus Culture Construction [J]. Technology Wind, 2015, (11): 193. 